\title{
NEPTUNO ALEGÓRICO: EMBLEMÁTICO ARCO EN LA OBRA DE SORJUANA
}

\author{
NEPTUNO ALEGÓRICO: AN ALLEGORICAL ARCHWAYIN SORJUANA’S WORK
}

Facundo Ruiz

UBA-CONICET

ABSTRACT: Frequently but unevenly valued, sor Juana Inés de la Cruz's (1648-1695) Neptuno alegórico [Allegorical Neptune] has received increased attention in recent years, as though -by virtue of its nature as «ephemeral art»- "that» art (emblematic) had become increasingly more meaningful than the fugacious situation from which it emerged. An exceptional text, the design of the triumphal archway that welcomed the new viceroy Tomás Antonio de la Cerda and his wife María Luisa Manrique de Lara in 1680, reveals not only the importance that sor Juana had already attained, to a great extent, as a writer, but also, and more emphatically, it shows the relevance of her public figure and, in a programatic sense, demonstrates a certain matrix for her literature.

Therefore, this study seeks to analyze the Neptuno alegórico in depth in order to reveal the three passages manifested in it: the one that converts the author into a (problematically) public figure; the one that displays in such an erudite and artistic manner a certain way of conceiving and practicing literary writing in the public sphere; and, finally, the one that places "that» literature (by Sor Juana) on a "gilded» map of Hispano-American literature.

KEYWORDS: sor Juana, Neptuno alegórico, Ttriumphal Arch, Ephemeral Art, Baroque

RESUMEN: Histórica pero desigualmente valorado, el Neptuno Alegórico de sor Juana Inés de la Cruz (México, 1648-1695) ha recibido en los últimos años una atención creciente, como si -en su carácter de "arte efímero»- tuviera cada vez más sentido «ese» arte (emblemático) que la fugacidad (coyuntural) que lo motivó. Texto singular, el diseño del arco triunfal que recibió en 1680 al nuevo virrey Tomás Antonio de la Cerda y a su esposa, María Luisa Manrique de Lara, pone en evidencia no sólo la importancia de la escritora que ya era -en buena medida- sor Juana sino, más enfáticamente, la relevancia de su figura pública y, de forma programática, cierta matriz para su literatura.

En este sentido, el presente trabajo se propone analizar detenidamente dicho texto a fin de concebir el pasaje triple allí manifiesto: el que convierte a esa escritora en una figura (problemáticamente) pública; el que exhibe tan erudita como artísticamente cierta forma de hacer y pensar la escritura literaria en el espacio público; y, finalmente, el que coloca "esa» literatura (sorjuanina) en un «áureo» mapa literario hispanoamericano.

PALABRAS CLAVES: sor Juana, Neptuno alegórico, arco triunfal, arte efímero, barroco

Fecha de recepción: 29-11-2011 / Fecha de aceptación: 20-6-2012 
El año de 1680 resulta, en los estudios barrocos, si no un momento bisagra, al menos una fecha emblemática, puesto que marcaría el principio del fin: el del esplendor áureo de la literatura y cultura españolas (que, ampliando el período propuesto por Ticknor, iría desde la publicación de la Gramática castellana de Nebrija en 1492 hasta la muerte de Calderón de la Barca en 1681). Sin embargo, y tratándose de estudios barrocos, poco indica el tiempo sin la consideración del espacio, esa variable que, sin ir más lejos, hace de la expresión "principio del fin» tanto un momento como un umbral, y entonces un paso o pasaje entre lugares que bien podrían vislumbrarse y distinguirse, más aún tratándose de emblemas, dadas su distribución, expresividad y potencia gráficas.

Ocurre que la «literatura española», en 1680, ya había trasladado algunos de sus límites y umbrales, diseminando tanto la temporalidad de sus esplendores como la geografía y nacionalidad que designaba. La cartografía de esa letra y de esa voz resultaba, si no más confusa gramaticalmente, al menos cultural y políticamente más compleja. Y la obra de sor Juana Inés de la Cruz (1648-1695), décima y americana musa -como entonces se la reconocía-, no sólo enfatiza este vaivén de traslados y cartografías complejas, sino que también indica, emblemáticamente, el arco que su literatura comenzaba a trazar en el campo de la cultura áurea, que siendo hispana ya no era estrictamente española.
Y entre los traslados y arcos de que fue testigo el año de 1680, se encuentra el Neptuno Alegórico ${ }^{1}$ de sor Juana, obra que debe ser leída no tanto (o no sólo) como la idea y descripción del arco triunfal con que fue recibido el nuevo virrey, Tomás Antonio de la Cerda, Conde de Paredes y Marqués de la Laguna, y su esposa María Luisa, sino como el texto que señala uno de los fundamentales pasajes (e incluso: virajes) de la obra y vida de la escritora mexicana -como vislumbraba Octavio Paz (1998) y confirmaba Antonio Alatorre (1986). Usualmente poco valorado, por su carácter de «texto por encargo" u "obrilla ciertamente menor y de puras circunstancias» (Puccini, 1997: 147), ${ }^{2}$ el Neptuno Alegórico se revela como un umbral crítico tanto de la situación de sor Juana como monja-escritora, en el marco de una sociedad colonial, como de la situación de su escritura, en el espacio de una cultura predominantemente masculina.

\section{ADMIRACIÓN PÚBLICA, ÍNTI- MAS RAZONES}

Amanecía el jueves 19 de septiembre de 1680 cuando el correo difundió por la ciudad de Nueva España la noticia de que el domingo anterior había llegado al puerto de Veracruz quien sería el próximo virrey acompañado de su esposa, la señora doña

1. Neptuno alegórico, océano de colores, simulacro politico, que erigió la muy esclarecida, sacra y augusta Iglesia Metropolitana de Méjico, en las lucidas alegóricas ideas de un Arco Triunfal que consagró obsequiosa y dedicó amante a la feliz entrada del Excelentísimo Señor Don Tomás Antonio Lorenzo Manuel de la Cerda, Manrique de Lara, Enríquez, Afán de Ribera, Portocarrero y Cárdenas, Conde de Paredes, Marqués de la Laguna, de la Orden y Caballería de Alcántara, Comendador de la Moraleja, del Consejo y Cámara de Indias y Junta de Guerra, Virrey, Gobernador y Capitán General de esta Nueva España y Presidente de la Real Audiencia que ella reside, etc.; Que hizo la Madre Juana Inés de la Cruz, religiosa del Convento de San Jerónimo de esta Ciudad, en sor Juana Inés de la Cruz, Obras completas IV. Comedias, sainetes y prosa. De ahora en adelante, y para evitar referencias confusas, cito $N A$ (Neptuno Alegórico) y el número de página correspondiente a la edición utilizada (2004: IV, 355-410)

2. Cabe destacar que el difundido prejuicio ante estos «textos por encargo» es absolutamente infundado no sólo estética sino históricamente, sostiéndose en la discutible «autonomía» del arte; sin referirme a las artes plásticas, la música, la ópera, el cine, o -y sobre todo- a la arquitectura: ¿no fueron la Eneida y El viejo y el mar, las crónicas de José Martí y el «Canto a la Argentina» de Rubén Darío, las Cartas de Hernán Cortés y las aventuras «post-mortem» del inolvidable Sherlock Holmes (y cada uno a su manera): textos por encargo? 
María Luisa Manrique de Lara y Gonzaga. ${ }^{3}$ Como ocurría desde el 22 de diciembre de 1528 , los recibimientos de gobernantes eran celebrados con arcos o portadas triunfales, de modo que sin dilaciones, como consta en las actas capitulares, el viernes 20 se trató el tema en la sesión del cabildo de la Iglesia Catedral Metropolitana de México. El arcediano Juan de la Cámara propuso encargar la concepción del arco al padre Valtierra; el tesorero Ignacio de Hoyos Santillana, evaluando la singularidad de la ocasión, y en vistas de que la cuidad había encargado el suyo al conocido Carlos de Sigüenza y Góngora, consideró más apropiado que fuera la madre Juana Inés de la Cruz quien llevara adelante el trabajo, por el cual debía pagarse, "sin que de esto se haga ni se alegue ejemplar en adelante», ${ }^{4}$ la generosa suma de 200 pesos (y no 150, como sugería el arcediano). Sólo un voto favorece a Valtierra: el cabildo elige a sor Juana. Consultado el arzobispo-virrey Fray Payo Enríquez de Rivera, se procede a comunicarlo a la monja. El 30 de noviembre (había llegado a la ciudad el 30 de octubre) entra oficialmente el virrey en Nueva España y dos arcos los reciben: uno del Ayuntamiento, otro de la Catedral. ${ }^{5}$

La situación, además de premura, exhibe cierta excepcionalidad. La elección de sor Juana es singular, y no sólo por tratarse de una mujer (Arenal, 2009: 11), sino porque pone en evidencia la dimensión de su figura como letrada. Como señala Alatorre (1986), la llegada del virrey y el encargo de idear el arco de la Catedral son decisivos en la vida de la escritora: poco después (c. 1682) decide terminar la conflictiva relación con su confesor y director espiritual, el padre Antonio Núñez de Miranda, y escribe la polémica carta, conocida como la de Monterrey (que es donde fue hallada por el padre Aureliano Tapia Méndez, quien la publicó en 1981, es decir, casi 3 siglos más tarde); y al mismo tiempo, entra en relación con los nuevos virreyes, y especialmente con la virreina, quien será no sólo amiga y protectora de la monja sino la que finalmente publique sus poesías en España. ${ }^{6}$ Por último, y como coinciden los críticos y estudiosos de su obra, podría describirse la década del ' 80 como la más intensa en la producción de la mexicana, así como también la más compleja o polémica. En cualquier caso, el Neptuno Alegórico podría considerarse la obra que inaugura definitivamente la fase pública (y política) de su carrera como escritora. ${ }^{7}$

Ya en el mismo año de 1680 se encuentran referencias elogiosas y significativas tanto para la obra como para su autora. Sigüenza y Góngora, en su Teatro de virtudes políticas que constituyen a un príncipe, amparado por una cita de Eurípides opta por

3. Cfr. Antonio de Robles, Diario de Sucesos notables (cit. en Salceda, 2004: XXXVI).

4. «Decreto capitular para que [a] la madre Juana Ynés de la Cruz, religiosa de Sn. Gerónimo, se le libren 200 p[esos] por haber hecho la idea del arco triunphal para el resevimiento del Sr. Virrey Marqués de Laguna» (firmado el 8 de noviembre), en Alatorre, 2007: I, 21.

5. Como sostiene Morales Folguera (1992), estos poderes (el laico del ayuntamiento y el religioso de la iglesia) solían disputar y promover sus propias fiestas, excepto cuando la celebración tenía «un carácter mixto» (447) o cuando se trataba de un poder «supramunicipal, el virrey» (448); e incluso afirma que «la colaboración entre ambas instituciones fue más frecuente de lo que en principio se podría pensar» (448).

6. Me refiero a Inundación Castálida (1689), primera edición de su obra reunida, aunque antes de 1680 habían sido publicados en México, de forma suelta, juegos de villancicos $(1676,1677,1679)$ y un poema (1668). Al respecto, véase también: Alatorre, 1987: 646.

7. Así, recientemente, en Grossi (2007: 91) y Arenal (2009: 30). Así también, en Alatorre: «Neptuno Alegórico -ese arco de doble triunfo: para el nuevo virrey de México y para la monja que al fin revelaba plenamente su talento», (1987: 640); quien años después, confirma: «A partir de 1680, gracias a la admiración producida por el Neptuno Alegórico, la vida de sor Juana comenzó a ser algo radicalmente distinto de lo que había sido. [...] No hay duda posible: el Neptuno Alegórico, prescindiendo de su peso intrínseco [...] fue para la autora el comienzo de su gran época (1680-1693), la que le ha dado un lugar permanente y glorioso en los anales de la literatura» (2010: 271).

IMAGO, NÚM. 4, 20I2, 23-39 
componer su arco con motivos y figuras precolombinos y no con las -comúnmente utilizadas- "mitológicas ideas de mentirosas fábulas» (1984: 172). ${ }^{8}$ Sin embargo -y a diferencia de lo que sugiere Olivares Zorrilla (2006: 107-108) y afirma Arenal (2009: 38)-, dedica prácticamente todo el Preludio III a la acertada preferencia de sor Juana para su arco, pues "[e]ntre los mentidos dioses sólo Neptuno tiene tan legitimada su alcurnia que es su nobiliario el Génesis y su historiador Moisés [...]» (1984: 177). Y luego de explicar la intención de lo dicho en el Preludio II (que "más tiene por objeto dar razón de lo que dispuse en el arco que perjudicar lo que [...] ideó la madre Juana Inés de la Cruz», 1984: 176), y de demostrar que Neptuno es hijo de Misraím, y por lo tanto, cuán pertinente y sabia ha sido la elección de la monja, dice de la escritora: "no hay pluma que pueda elevarse a la eminencia donde la suya descuella, cuánto y más atreverse a profanar la sublimidad de la erudición que la adorna» (1984: 177); y enseguida, repara en «la reverencia con que debemos aplaudir sus obras" dado que se trata «del peregrino ingenio de la madre Juana Inés de la Cruz, cuya fama y cuyo nombre se acabará con el mundo» (1984: 183) $)^{9}$ [fig. 1].

También Juan Antonio Ramírez de Santibañez, en su Piérica narración [...] publicada en diciembre, es decir, pocos días después de la entrada del virrey, y en la cual, entre otros, se describen los festejos de la bienvenida, se refiere a los arcos. Sin embargo, y aunque les dedica 5 quintillas, no nombra a Sigüenza; pero sí a sor Juana: «Su autor bien será que cuadre, / pues la Madre Juana fue, / cuya armonía no descuadre, / porque se vio que el mar de / Neptuno salió de

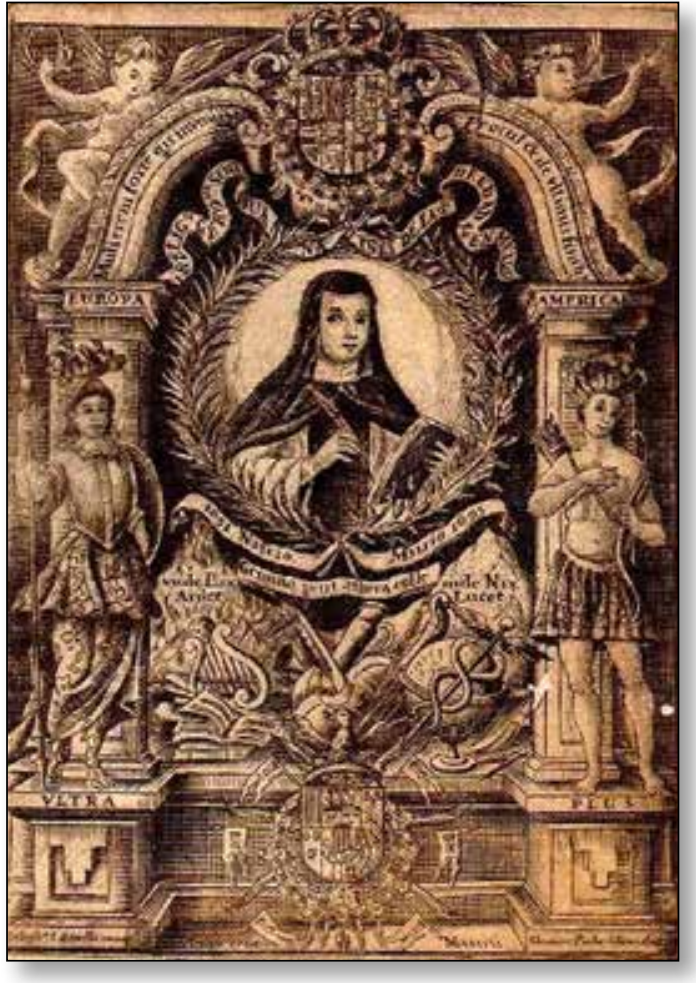

Fig. 1. Portada de Fama y Obras Póstumas. 1700.

Madre» (en Alatorre, 2007: 26). De donde podría inferirse, que no "por bien sabido" (como explica Alatorre, 2007: 25) deja de nombrar a Sigüenza, sino que "por fuerza mayor» coloca el de la jerónima: sor Juana se ha vuelto pública como escritora; su nombre se distingue en espacio de la literatura.

De 1684 es el extrañísimo (y maravilloso) libro, Debido recuerdo [...], que José López de Avilés dedica a recordar los beneficios que el arzobispo-virrey Fray Payo ha hecho por la ciudad de México. El poema, de 2094 versos y 864 apostillas, sobre el final alude a los nuevos virreyes (sobrinos de Fray Payo), y se detiene a exclamar: « $\mathrm{OH}$

8. Quizás no se tratara de una decisión o preferencia sólo personal: «la Contrarreforma prefería los personajes históricos a los mitológicos cuando se iban a utilizar como paradigmas de virtud» (López Poza, 2003: 251). Y cabe recordar que tanto la degradación de dioses paganos (por el cristianismo) como «la procesión de dioses destronados» (o muertos) constituían ecos carnavalescos que señalan de un modo festivo un pasado, o viejo mundo, «en fuga» (cfr. Bajtín, 1990: 353 y ss.).

9. Probablemente, los versos 61-64 de la «Explicación del arco» (NA: 404) hayan sido destinados por sor Juana al elogio sesgado - pero público- del arco ideado por su amigo. 
NEPTUNO erudito! / ¡Quién pudiera ponerte en este escrito, / o neblí venturoso se tornara, / que al remonte la pluma le quitara I a la cándida garza caudalosa!» (en Alatorre, 2007: 31), y tras elogiar brevemente y entre paréntesis a quien lo ha escrito, continúa recordando..$^{10} \mathrm{La}$ apostilla a "cándida garza" (inimitable epíteto de sabor modernista), tras un juego de citas y anagramas, no sólo caracteriza «el singular ingenio de América" como "cisne blanquísimo" sino como "ave rara", en consonancia tal vez con el «Fénix de indiano parnaso» (1676) y el «mexicano Fénix de la poesía» (1681), como ya había sido llamada (cfr. Alatorre, 2007: I). La distinción pública, que el nombre de la escritora suscitaba en 1680, rápidamente devenía monstruosa diferencia (cfr. Glantz, 1994) [fig. 2].

Tampoco deja de nombrarse el Arco en el «Prólogo al lector» de Inundación Castálida de 1689, donde vuelve a publicarse el Neptuno Alegórico ${ }^{11}$ y donde aparece la décima $\left(n^{\circ} 115\right)$ en la que la poetisa agradece, irónicamente, el pago por haberlo hecho; ni lo eluden las censuras y aprobaciones panegíricas del Segundo Volumen (1692), donde fray Gaspar Franco de Ulloa lo describe como "un compendio tan universal de todas las ciencias" (en Alatorre, 2007: 136). Por último, cabe destacar otras dos menciones del Arco: por un lado, la de José Zatrilla y Vico, Conde de Villasalto, en su Poema heroyco al merecido aplauso del único oráculo de las musas [...] de 1696 (al año siguiente de la muerte de sor Juana), ya que -como dice Alatorre-: "Los elogiadores de sor Juana suelen destacar el Sueño y la Crisis del sermón de Vieira; Zatrilla, en cambio, parece haber admirado especialmente el Neptuno Alegórico, pues alude a él tres veces (octavas

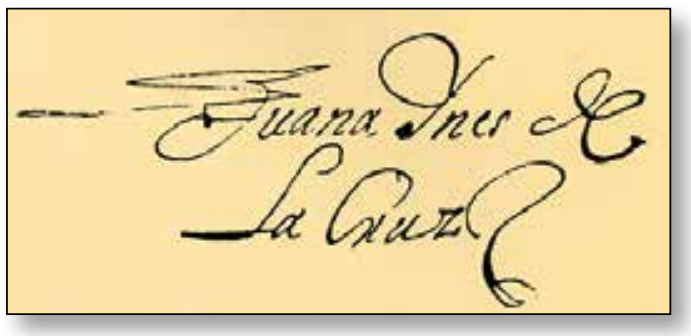

Fig. 2. Firma de sor Juana en 1686.

53, 82 y 95)" (2007: 230); y por otro lado, la de Joannis Michaelis von der Ketten en su Apelles symbolicus [...] de 1699, obra especializada y dirigida a "poetas, prosistas y predicadores" a quienes, comenta Alatorre, "ofrece un amplísimo repertorio de símbolos, figuras, imágenes, emblemas, ideas representables [y] metáforas» (2007: 231); obra que incluye, como "símbolos dignos de figurar al lado de los del famoso Emmanuele Tesauro» (Ibíd.), cuatro referentes a Neptuno (y hasta entonces figuraban sólo dos) tomados de la obra de la mexicana.

Como queda visto, el Neptuno Alegórico, esa «literatura de aparato» (Hinojo Andrés, 2003: 184), revela cierto viraje en la vida y obra de sor Juana. Es cierto que su lectura (y textura) resultaron y resultan extrañas a cierta crítica. Sin embargo, y entre otros, el estudio de la emblemática ha permitido acercamientos nuevos y lecturas productivas o sugerentes (cfr. Buxó, 2002 $2^{12}$ y Rodríguez de la Flor, 2009), dado que su perspectiva permite pensar y enlazar ciertas imágenes y los textos que las acompañan a usos e intenciones, necesidades y concepciones, que hoy podrían resultar, a priori, incomprensibles o anacrónicos. En cualquier caso, y siguiendo el diseño expresivo del emblema triplex, propongo a continuación tres posibles entradas al Neptuno Alegó-

10. Sor Juana escribe la décima 111 (2004: I, 248-249) en alabanza de la «docta pluma» de López de Avilés (esta décima fue publicada en 1692 en el Segundo Volumen de las obras de sor Juana).

11. «Primera edición, aislada, 'En México, por Juan de Ribera, en el Empredadillo', sin fecha, pero seguramente muy poco posterior a la entrada solemne», anota Alberto G. Salceda (2004: IV, 597).

12. En el caso particular de Buxó, podría leerse en miniatura el cambio que se produce (al menos en la crítica latinoamericana) respecto de la concepción y lectura de los arcos y emblemas: cfr. 1959 y 2002.

IMAGO, NÚM. 4, 20I2, 23-39 
rico (como si de un gran emblema de este viraje se tratara): en primer lugar o mote, a través de la dedicatoria y la "Razón de la fábrica alegórica, y aplicación de la fábula»; en segundo lugar o pictura, a través de la descripción de los "Argumentos» de los lienzos o tableros, las basas y los intercolumnios; en tercer lugar o epigrama, a través de la «Explicación del Arco» en verso.

\section{MUNERE TRIPLEX: LAS MANERAS DE ESCRIBIR}

"Costumbre fue de la antigüedad, y muy especialmente de los egipcios, adorar sus deidades debajo de diferentes jeroglíficos y formas varias» (NA: 355), comienza diciendo la dedicatoria, y enseguida se distinguen dos líneas que guiarán la concepción del Arco: una, genealógica, que fundamentalmente se desarrollará a través de abundantes citas en latín y fabulosas etimologías; otra, imaginaria, que principalmente planteará el problema de la articulación de un plano religioso-político y otro formalrepresentativo. Y si bien la articulación muchas veces adoptará la forma genealógica y las genealogías serán el resultado de una articulación imaginaria (como ocurría con Sigüenza y Góngora para el caso de Misraím-Neptuno, y también en sor Juana para Neptuno-Marqués de Laguna, cfr. NA: 366-372), ambas líneas están contenidas en un espacio más amplio y conflictivo que es el plano de expresión, donde todo -de una $\mathrm{u}$ otra manera- puede aparecer y mostrarse a los ojos (así sean los del espíritu). ${ }^{13} \mathrm{Y}$ puesto que la costumbre es expresar las deidades (sea para adorarlas, sea para invocarlas), se pregunta sor Juana: ¿cómo hacer visible lo invisible?, ¿cómo formular aquello que no tiene forma? Y se responde: "como eran cosas que carecían de toda forma visible, y por consiguiente, imposibles de mostrarse a los ojos de los hombres [...] fue necesario buscarles jeroglíficos, que por similitud, ya que no por perfecta imagen, las representasen" (NA: 355-356). Sin embargo, y aún cuando este modo de expresión por similitud no deja de resultarle paradójico (puesto que supone que «la Deidad, siendo infinita" puede "estrecharse a la figura y término de cuantidad limitada", NA: 355), es recomendable, "por atraer los hombres al culto $[\ldots]$ por reverencia de las deidades, [y] por no vulgarizar sus misterios a la gente común e ignorante» (NA: 356). De modo que los jeroglíficos semejan, esto es, expresan por semejanza; pero, dado que lo semejado no es accesible, "el sentido de la semejanza cambia completamente de función: la semejanza se juzga por lo semejante, no por lo semejado" (Deleuze, 1989: 124). El modelo pasa a ser el resultado de una relación, y no el punto de partida de una secuencia.

Dos elementos, característicos del uso de emblemas, no deberían pasarse por alto en esta concepción: en primer lugar, el carácter ideal que en cierta medida tiene la "deidad" (o cosa a expresar), ya que carecer de forma visible no le impide ser inteligible, todo lo cual reformula el problema en términos de cómo hacer visible lo inteligible; en segundo lugar, el funcionamiento de coincidentia oppositorum (o discordia concors) que adquiere la expresión: lo infinito puede ser limitado; lo limitado puede expresar lo infinito (cfr. Deleuze, 2002: 170-182). En la perspectiva de Bouzy, ambos elementos estarían subrayando no sólo el «conceptismo didáctico del emblema» (1993: 39) sino la intención publicitaria o propagandística subyacente: «Penetrar en las mentes halagando los

13. Si «la necesidad de ciertas sociedades [diglósicas] de marcar los rangos más altos del grupo utilizando recursos lingüísticos» configuró «variedades lingüísticas sólo accesibles verbalmente a minorías selectas», en el caso de «los arcos triunfales, sin embargo, las mayorías pudieron comprender el sentido general de los textos gracias a elementos plásticos que acompañaban a los textos» (Parodi, 2008: 481). 
sentidos es el objetivo primordial [...] del emblema» (1993: 40). ${ }^{14} \mathrm{Y}$ a esto sin duda se refiriere el texto cuando habla de "atraer al culto» sin "vulgarizar»: formar figuras visibles capaces de encantar y entretener, sin ofrecer por eso la clave de la formalización; o también, hacer pública una imagen (y su imaginario) mientras su secreto continúa (imaginariamente) en un ámbito íntimo y hasta privado. ${ }^{15} \mathrm{Y}$ el Arco adopta, entre otras, esta inflexión didáctica y propedéutica, como se ve -por ejemplo- en la identificación de Neptuno y Conso (dios del consejo) analizada por Olivares Zorrilla (1995: 385 y 2006: 93-94). En este sentido, cada uno de los motes indicará una virtud que el príncipe debe tener y cultivar (o que, "nobleza obliga», tiene y cultiva); cada uno de los motivos aludirá a escenas significativas no sólo en relación a la forma de gobierno, sino al modo en que el gobernante debe conducirlo y conducirse (y es particularmente notoria, en el Neptuno Alegórico, la insistencia sobre cualidades y acciones que refieran al autodominio racional y, en el espacio extra-individual, a la "contienda" o guerra "de entendimientos», donde las leyes y letras, no suspendidas por las armas, funcionan constante y discursivamente, cfr. $N A$ : 388-392). No obstante, y dado que la semejanza se juzga por lo semejante, la "clave» oculta al vulgo expresa, otra vez, más una potencialidad o prospección que una esencialidad o preceptiva, abriendo otro campo de especulación: ya no el moral-judicial del ser (o deber ser), sino el ético-político del poder (o poder hacer).

Ambos elementos (el carácter ideal y la coincidentia oppositorum) forman parte importante del espectro especulativo-filosófico que, como demuestra García Arranz, constituye el «peculiar proceso de configuración» (2002: 231) del jeroglífico «humanista" de los siglos XV y XVI, base de la concepción emblemática del siglo XVII. En este sentido, el carácter ideal y visual de los signos se enlazaba con cierta tradición neo/platónica que privilegiaba un pensamiento opuesto al discursivo y a través del cual signo y concepto se presentan de un solo golpe, intuitivamente. El jeroglífico permitía el verdadero conocimiento (en el marco de una concepción alegórica de la naturaleza de las cosas) ya que las ideas eran visual y directamente contempladas: «El jeroglífico no expresa tan sólo una idea, sino su esencia, su forma platónica, perfecta y completa en sí misma: es un 'modelo filosófico de perfección no verbal'» (García Arranz, 2002: 232). Y si sor Juana no es ajena a esta concepción (y como muchos contemporáneos, gusta de «lo condensado»), tampoco se ajusta a ella de manera canónica: como se ha visto, la expresión por similitud del jeroglífico representaba aunque «no por perfecta imagen». En este caso la imagen, aún siendo capaz de abstracción (o de idear), más que ofrecer una idea en su simple naturaleza, expresa de un solo golpe la relación compleja, el punto en el cual se cruzan líneas disímiles y hasta natural-

14. «Insistamos, pues, en que los arcos tenían un doble propósito: propagandístico y educacional» (Sabat de Rivers, 1992: 246). Cfr. también: López Poza, 2003: 243; y Olivares Zorrilla, 1995: 368

15. Serge Gruzinski se ocupa de la «imagen barroca» pero en un sentido, principalmente, religioso (Virgen de Guadalupe), polarizando en el ámbito político (a mí modo de ver) abruptamente el arte efímero (como los arcos) y la imagen de culto religiosa, que considera «antípodas». Aunque aclara que esta polaridad funciona fundamentalmente en el siglo XVI (aprox. 1550-1650), creo que su análisis es, si no fundamental, al menos muy útil o sugerente para pensar la función pública y vinculante de los arcos (cfr. 2003: 145, 146 y 151).

16. «He aquí el meollo de la cuestión. Lo que importa no es propiamente la comunidad o semejanza del modelo remoto con el sujeto actual, sino la concordancia o analogía proporcional que pueda establecerse entre aquellos 'extremos cognoscibles', esto es, entre la imagen del dios de las aguas y el Marqués de Laguna, el cual -extremando la hipérbole-, no es posible representar al vivo, pues su misma naturaleza, esto es, la extrema perfección a él atribuida, excede todo posibilidad de mimesis cabal» (Buxó, 2002:134). Cfr. también Olivares Zorrilla (1995: 371). 
mente contradictorias: lo limitado expresa lo infinito. ${ }^{16} \mathrm{Y}$ entonces un Arco expresa la grandeza (innumerable, $N A: 356)$ de $u n$ príncipe (atemporal), o del Príncipe (eterno). La imagen es perfectible, no perfecta: la clave es proyectiva, o producible (no preceptiva ni producida). El programa queda a la vista. La imagen expresa el resultado de una relación, su acaecer: la coincidencia, por ejemplo, de un hombre (Marqués de Laguna) y un conjunto de virtudes o cualidades divinas (Isis/Neptuno); o también: la paradoja de inaugurar con un Arco el principio del algo cuya duración es eterna; y también: la conjunción singular (designada Neptuno) y trina (simbolizada con el tridente), de lo terrestre y sólido (Conde de Paredes), lo acuático y líquido (Marqués de Laguna), y lo celeste y aéreo (nube tonans: padre de gigantes pensamientos [NA: 395396] y sabios centauros ${ }^{17}$ ).

Ahora bien, reflexiona sor Juana en la «Razón de la fábrica alegórica»: si la expresión por similitud del jeroglífico se juzga por lo semejante y no por lo semejado, es decir, si el modelo es el resultado de una relación, que la imagen expone: ¿cómo se la escribe? Esto es: ¿cómo expresar esa relación singular por escrito? Se trata, ahora, de encontrar una "manera de escribir" (NA: 359) adecuada a cierta relación singular que quiere expresarse. Y en primer lugar, sor Juana ensaya un procedimiento genético o método de Naturaleza:

Y ya dispuesta la voluntad a obedecer [el "mandato" de hacer el Arco], quiso el discurso no salir del método tan aprobado de elegir idea en que delinear las proezas del héroe que se celebra, o ya porque entre lo fingido campean más luces de lo verdadero [...] o ya por sea decoro copiar el reflejo, como en un cristal, las perfecciones que sin inaccesibles en el original ${ }^{18}[\ldots]$ o ya porque en la comparación resaltan más las perfecciones que se copian [...] o ya porque la Naturaleza, con las cosas muy grandes, se ha como un diestro artífice, que para hacer la obra a todas luces perfecta, forma primero diversos modelos y ejemplares [...] y así ninguna cosa vemos muy insigne (aun en las sagradas letras) a quien no hayan precedido diversas figuras que como dibujo la representen (NA: 358-359).

De esta manera, se deben hacer diversas figuras (modélicas o ejemplares ${ }^{19}$ generadas), para luego expresar o generar lo «muy insigne». Lo perfecto está precedido de modelos, que en cierta medida, expresan genéticamente la perfección pero sin acabarla o completarla. Una palabra frecuente y reveladora en el texto del Arco es el verbo «delinear»: escribir - parece pensar sor Juana- es trazar un conjunto de líneas capaces de expresar una relación singular. La singularidad de la relación radica en la reunión única de líneas diversas (y hasta opuestas) que allí se realiza. La unicidad de esta reunión no puede ser una idea simple sino un complejo tejido de ciertas variantes (de líneas comunes ${ }^{20}$ ). Expresar el complejo singular y único de esa relación será entonces delinearla: distinguirla en líneas reconocibles, o al menos, legibles. Trazar sus líneas: expresarlas. Expresar relaciones: revelarlas. Revelaras: darlas a conocer, convertirlas en (objetos de) conocimiento.

17. Cfr la relación etimológica (y genético-gnoseológica): «siendo el nombre de Neptuno lo mismo (en sentir de san Isidoro) que nube tonans, ¿quién quita que le prohijemos éstos [centauros-sabios] que, así por la etimología de su nombre [«Cineos Doctos», NA: 383-384] como por su ciencia, pueden con tanta razón legitimarse hijos suyos?» (NA: 384).

18. Quizás no sea inútil recordar, amén de lo ya dicho acerca del carácter ideal de lo que se pretende expresar, que sor Juana aún no conocía (personalmente) a los Virreyes.

19. De «prototipo» se hablará en la «Explicación del arco» (NA: 408, v. 212).

20. Llamo línea común, por ejemplo, a «hombre»; cuya variación «Príncipe», y sus determinaciones «Conde de Paredes/Marqués de Laguna», «nuevo virrey de Nueva España, ciudad lacustre», etc. van distinguiendo de forma única, o singularizando como relación-compleja esa imagen, esa variación. 
Así, lo perfecto a representar resulta de la combinación de modelos (o grados de perfección). Los modelos se producirán por composición (de perfecciones, de cualidades y cantidades, de líneas, de ideas); lo perfecto se producirá por combinación. En los modelos o ejemplos la perfección es particular (compone); lo perfecto debe ser completo: combinará (que no es lo mismo que adicionar) todas las perfecciones de forma única; o lo que es lo mismo: de todas las formas posibles en su máxima perfección (aunque eso sea ininteligible, en tanto esa combinatoria maneja todas las variaciones en su máximos y eternamente, Cfr. Gilles Deleuze, 1989 y 2002).

Esta, pues, tan decorosa invención me obligó a discurrir entre los héroes que celebra la antigüedad, las proezas que más combinación tuviesen con las claras virtudes del Excelentísimo Señor Marqués de la Laguna (NA: 359, cursivas mías).

Sin embargo, sor Juana (hiperbólica e irónica, aunque necesariamente más lisonjera) encuentra un límite o problema al método de Naturaleza: no hay nada similar, nada de donde sacar copia, nada compuesto y capaz de ser combinado para imaginar (formar imagen) del Marqués: "no hallé cosa que aun en asomos se asimilase a sus incomparables prendas» (Ibíd.). El método debe cambiar:

pues parece que la Naturaleza, como falta de fuerzas y suficiencia, no se atrevió a ejecutar, ni aun en sombras, lo que después a esmeros de la Providencia salió a lucir al mundo en su perfectísimo original; y así dejó que el pensamiento formase una idea en que delinearlo; porque a lo que no cabía en los límites naturales, se le diese toda la latitud de lo imaginado (Ibíd.).

Este nuevo método (o «manera de escribir», según el propio texto), y que podría denominarse método de Providencia, ya no trabaja con modelos o ejemplos a los «que enmendar y pulir lo que no fuere tan perfecto" (Ibíd.), sino que sale al encuentro del perfectísimo original: suspende la serie, arbitraria pero declinable o derivable; y se salta al origen (Ursprung), inventándolo. Y recién entonces: delinea, traza, concibe la figura. Y esta invención responde, fundamentalmente, no a una creatio ex nihilo sino a un ars inveniendi: lo que se produce es un cambio de naturaleza, una interrupción de la serie (de modelos o ejemplos) que hace saltar el elemento expresado de una relación a otra (de una reunión única de líneas diversas a una reunión distinta y también única...): es así como Neptuno fue hombre, que al entrar en composición con características inusuales a su serie (como quienes son "inventores de las cosas»), se convirtió en un príncipe excelente, y así devino dios: divinidad para los gentiles (lo que puso su historia en relación con mitológicas ideas, pues «las fábulas tienen las más su fundamento en sucesos verdaderos»); y ahora, bajo luz cristiana, entra en la serie de los príncipes, esto es, vuelve a ser hombre (u hombre-Virrey), pero en cierta medida: también es el Príncipe, hijo del Rey Único Señor. Excepcional o «excelentísimo», nada lo precede, porque él, sin ser el inicio, inaugura (cfr. $N A: 359$ ).

Esta diferenciación (sin separación) en el plano de expresión de maneras de escribir conforma distintos métodos o procedimientos (composición, combinación, invención) que no sólo hacen del $N A$ un texto complejo y fabuloso (en más de un sentido); sino que, y como se dijo inicialmente, exhiben en 1680 cierto diseño productivo para la obra de sor Juana, así como cierta idea de la (propia) escritura. Y este diseño (táctico-estratégico al mismo tiempo, si se recuerda la conflictiva relación con Núñez de Miranda), le permite hacer un Arco: idearlo; pero a través de él, distinguir ciertas ideas, y sobre todo: distinguirse (conformar cierta imagen propia). 


\section{ASTERIA, PERSEGUIDA, SE EMPLUMA Y AÍSLA. PERO LA ISLA SE MUEVE}

Entre las muchas imágenes (y autoimágenes) con que se ha reconocido y pensado a sor Juana, no suele abundar la de «aquella casta Asteria, cuya belleza vistió de plumas a la deidad de Jove» (NA: 378), motivo del tercer lienzo del $N A$ (378-381). ${ }^{21}$

El edificio diseñado o "fábrica» (NA: 373) tenía 30 varas de alto $\times 16$ de ancho (Sabat de Rivers, 1992: 248 y López Poza, 2003: 254), o 25, 14 metros de alto x 13,408 de ancho (Salceda, 2004: IV, 608 y Arenal, 2009: 19), donde se distribuían 8 lienzos (cada uno con mote, "argumento", y epigrama), 4 basas (dos a derecha, dos a izquierda) y dos intercolumnios (cuya pictura, a diferencia de las restantes, tomaba como eje a la virreina María Luisa). De los lienzos no se conoce el ejecutor o pintor (a diferencia de lo que ocurre con el arco de Sigüenza y Góngora). Así «ensaya» Sabat de Rivers (1992: 244) su ilustración [fig. 3].

Naturalmente, la descripción de los «argumentos» de los lienzos está numéricamente ordenada en el texto, lo que permite una lectura diferente si se sigue la ilustración de Rivers: ya no secuencial, sino posicional. Sin ir más lejos, el centro del edificio está ocupado por el lienzo 1, donde se veía a Neptuno y a su esposa Anfitrite en un carro [figs. 4 y 5], deslizándose sobre la superficie

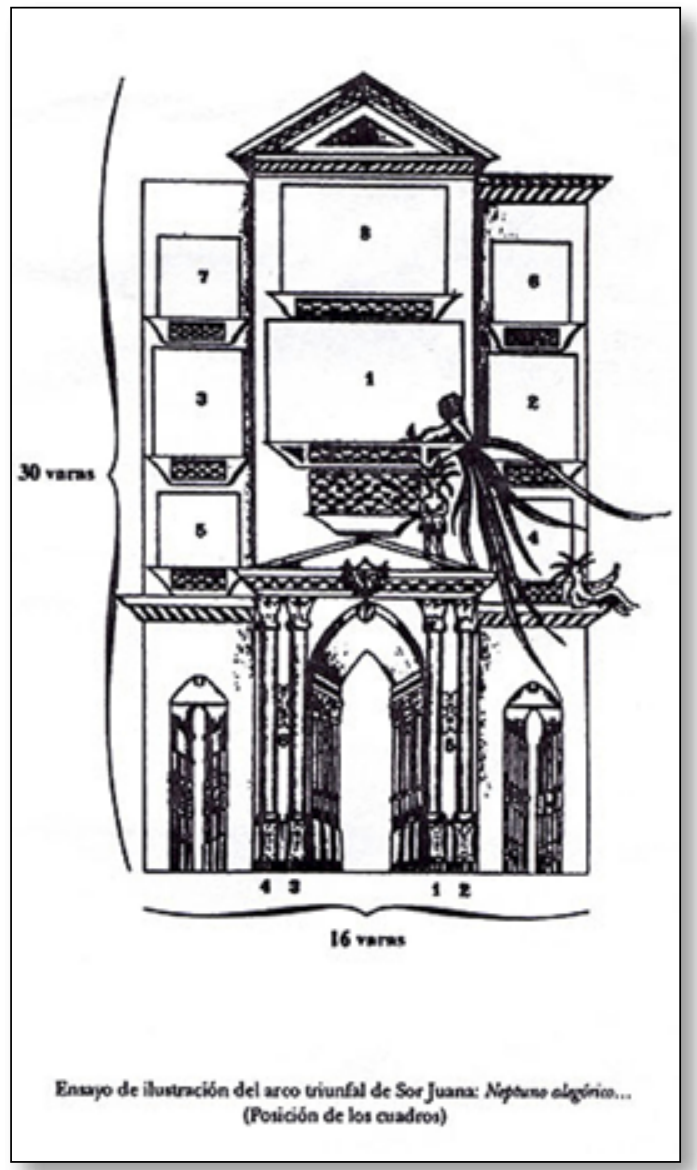

Fig. 3. Sabat de Rivers, ilustración del arco (Neptuno Alegórico).

del mar y rodeados de una marítima comitiva [fig. 6], tal cual «lo escribe Cartario» (NA: 375) [fig. 7]; pero también por el lienzo 8, donde «se pintó el magnífico Templo Meji-

21. Octavio Paz dedica un capítulo entero a la relación sor Juana-Isis. Es cierto que no es menor dicha conjunción, sobre todo cuando a Isis se la identifica con la sabiduría y con la creadora de las letras, se hace descender a Neptuno de ella, y se le adjudica (vía Jacobo Bolduc) una curiosa etimología: Is = varón; Is-Is = dos veces varón (NA: 366). Todo lo cual coincide con la perspectiva psicológica de Paz (a través de la cual la monja sería -también- «madre», «sabia» y «viuda», entendiendo que transforma al padre ausente en marido muerto), y con el escenario cultural por él propuesto (masculino; y donde prima la egiptomanía: «una de las enfermedades intelectuales de su siglo», 1998: 236); aunque se relacione poco con la propuesta bibliográfica (como sostiene Serrato Córdova, 1995: 438); puesto que como el mismo Paz indica (1998: 237) -y pese a su insistencia, y la de Arenal (2009: 25)- sor Juana no cita a Kircher en el NA. Sin embargo, no es mi intención ocuparme de esta relación, entre otras cosas porque el capítulo de Paz es suficientemente sugerente, sea en la dirección que sea. Por otra parte, no creo que en 1680 funcionara una imagen tan poderosa en la especulación de sor Juana sobre sí misma; sino más bien una imagen esquiva, acechada, pero estratégica como lo es Asteria, una diosa menor, lateral, y a la deriva, pero que dispone del espacio necesario (oscuro) para que nazca Apolo, acción que -según el $N A$ - el «dios de los mares» (y no Zeus-Jove, como se encuentra usualmente en la mitología) recompensaría muy favorablemente. 


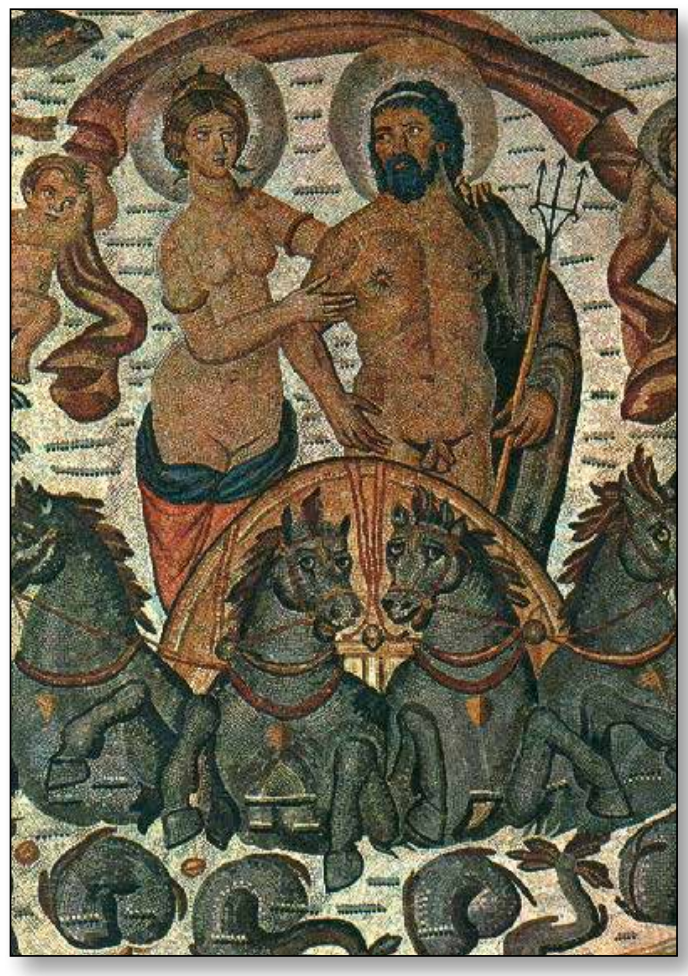

Fig. 4. El triunfo de Neptuno y Anfitrite (detalle; mosaico romano).

cano de hermosa arquitectura, aunque sin su última perfección", es decir, inconcluso y aguardando el auxilio «de su patrón y tutelar Neptuno, nuestro excelentísimo héroe» (NA: 392). Dejando de lado que el texto usa la expresión "vistoso centro» sólo para el primero, cuando el octavo, si «último», también "coronó la montea» ${ }^{22}$, resulta evidente no sólo la mayor cercanía del Templo con el cielo, sino la situación disímil, que coloca a ambos poderes en la misma vertical (o "pirámide»" ${ }^{23}$ ), aunque al político por debajo del religioso (el que, por otra parte, había financiado la obra). No habría que olvidar, como comenta Serrato Córdova, que

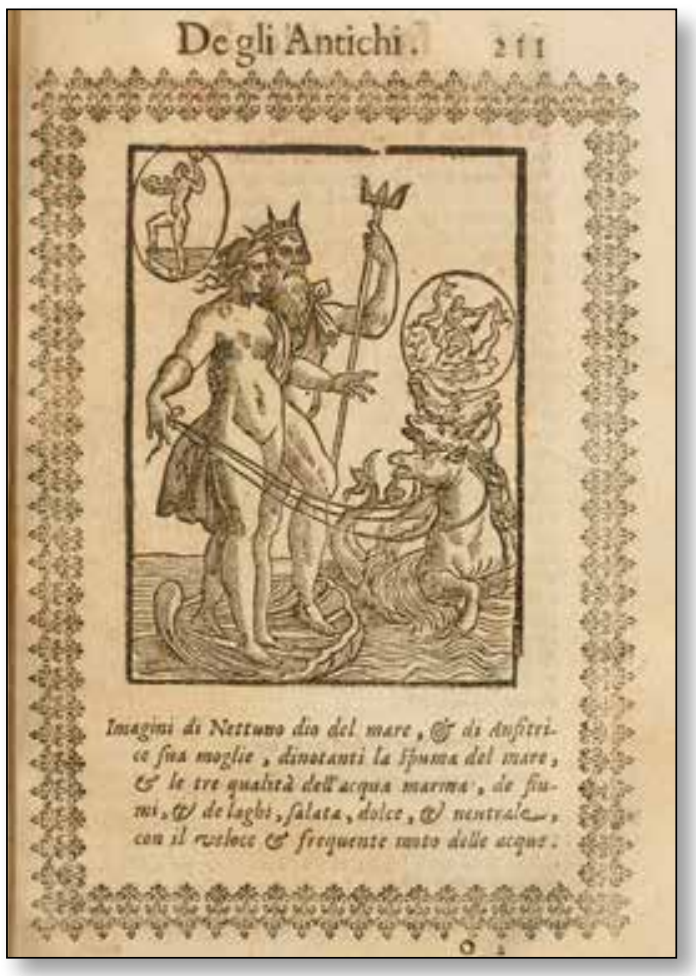

Fig. 5. Página de Le Imagini de i Dei de gli Antichi de Vicenzo Cartari.

el «Neptuno alegórico, obra laudatoria [...] bien puede estudiarse como poesía política» (1995: 437).

No obstante esta posibilidad (y acentuado lo político de esta poesía), la lectura secuencial de los argumentos compone una narración o relato, cuyo héroe naturalmente es Neptuno -o el virrey-, quien al estar fuertemente caracterizado por sus virtudes y actitudes intelectuales (como se ha dicho), finaliza la saga (lienzo 7) compitiendo con Minerva por el nombre que a la ciudad (de Atenas) debía ponerse. ${ }^{24}$ Sin exagerar ni solapar otras lecturas, pero teniendo en cuenta -como precisa Olivares Zorrilla (1995:

22. En la «Explicación del arco», en cambio, de cada lienzo se dice que «corona» la portada (NA, vv. 70 y 260).

23. La inscripción latina (coronando la portada) decía sobre el final: «Metropolitana Imperialis Mexicana Ecclesia hunc obsequii, et vivi amoris obeliscum, hanc communis gaudii publicam tesseran, hoc perennaturae felicitatis votum auspicatur» (NA: 374); que Salceda traduce en las notas como: «la Metropolitana Iglesia Mejicana este obelisco de rendimiento y vivo amor, esta insignia pública del gozo común, este voto de felicidad perdurable ofrece en augurio» (2004: IV, 609). 


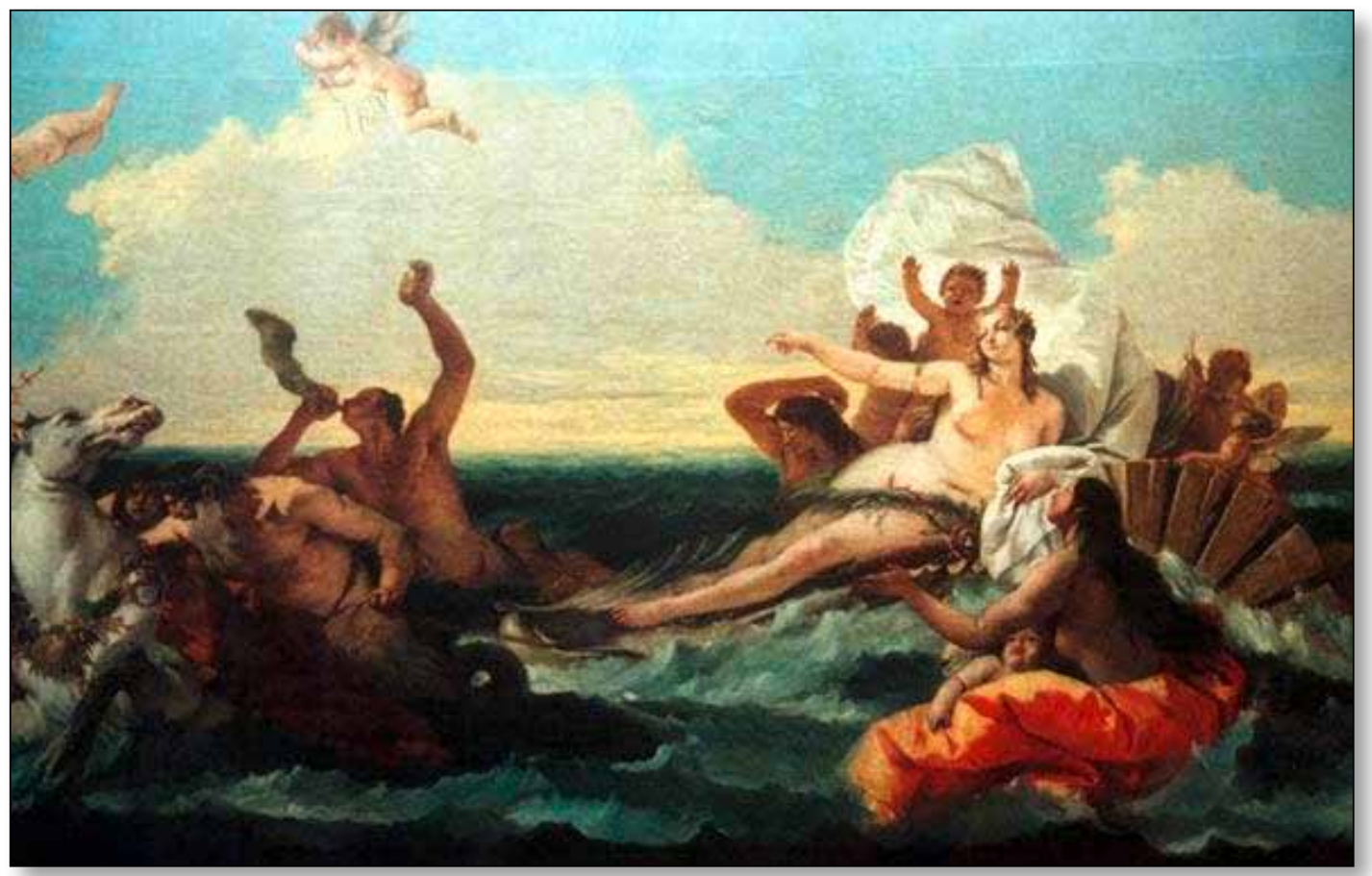

Fig. 6. Giovanni Battista Tiepolo, El triunfo de Anfitrite. 1739.

372) - el traslado de ciertos principios retóricos a las artes plásticas realizado en el Renacimiento (por Alberti, Gáurico y Lomazzo) y la importancia que adquiere la istoria (tema o fábula) en la pictura (imagen), tal vez podría leerse el NA como la única "narración» de sor Juana, roman-ciertamente-à clef, que (como las otras claves ya mencionadas) se encuentra más adelante, es decir, en su proyección o programa. Me refiero a la Respues- ta a sor Filotea de la Cruz, puesto que ambos textos cifran buena parte de sus peripecias en el lugar y las vicisitudes del saber y de quienes a él se pliegan; ambos textos privilegian ciertas figuras femeninas para referirse al conocimiento; y por último, ambos textos encuentran a sor Juana ante una situación difícil, obligándola a configurar una imagen esquiva, acechada, pero decididamente estratégica: la de Asteria. ${ }^{25}$

24. Como analiza Olivares Zorrilla, hay en la relación Neptuno/Conso-Minerva, son sólo un vínculo claro (vía Plutarco y Cesare Ripa) sino claramente simbólico, puesto que la lechuza alude tanto a los consejos y decisiones como (vía Erasmo y Covarrubias) «a los consejos y decisiones que tienen lugar en la oscuridad de la noche» (2006: 94), todo lo cual «le ofrece a la autora los hilos necesarios para tejer la red simbólica entre sus propios textos» (2006: 95); red en la cual el silencio (Harpócrates) ocupa un lugar central, según Olivares Zorrilla, y a diferencia de considera Serrato Córdova (1995: 438-439), para quien el uso de emblemas no apunta a ningún «lado oscuro de la sabiduría» sino al «placer que la poetisa experimenta por buscar y enlazar refinadísimas citas eruditas de una manera ingeniosa y juguetona».

25. La «narración» (resumida) del $N A$ comienza con la llegada de Neptuno (lienzo 1), y su oportuna intervención en la ciudad, que «ocupada de las saladas iras del mar» (NA: 377) e invadida por «marinos monstruos» (NA: 378), amenazaba perderse (lienzo 2). Una vez fijada, la «isla [...] apareció al mundo»: «pues el temor de éste [el mar] estorbaba su descubrimiento» (lienzo 3). Entonces se muestra la piedad de Neptuno hacia Eneas, perdedor de la guerra (de Troya), y perseguido por Aquiles (lienzo 4). Acto seguido Neptuno, «tutelar numen de las ciencias» (NA: 382), recibe a los doctísimos centauros (lienzo 5) y coloca entre los astros al delfín-ministro, por sus insustituibles servicios (lienzo 6). Una vez establecida esta calma, se procede a nombrar la ciudad a través de una competencia de ingenios donde Neptuno es vencido por Minerva, que no es otra que su sabiduría: controlado (auto-gobernado), puede gobernar (lienzo 7). Sólo resta construir, con la «bondad» como compañera (lienzo 8). 


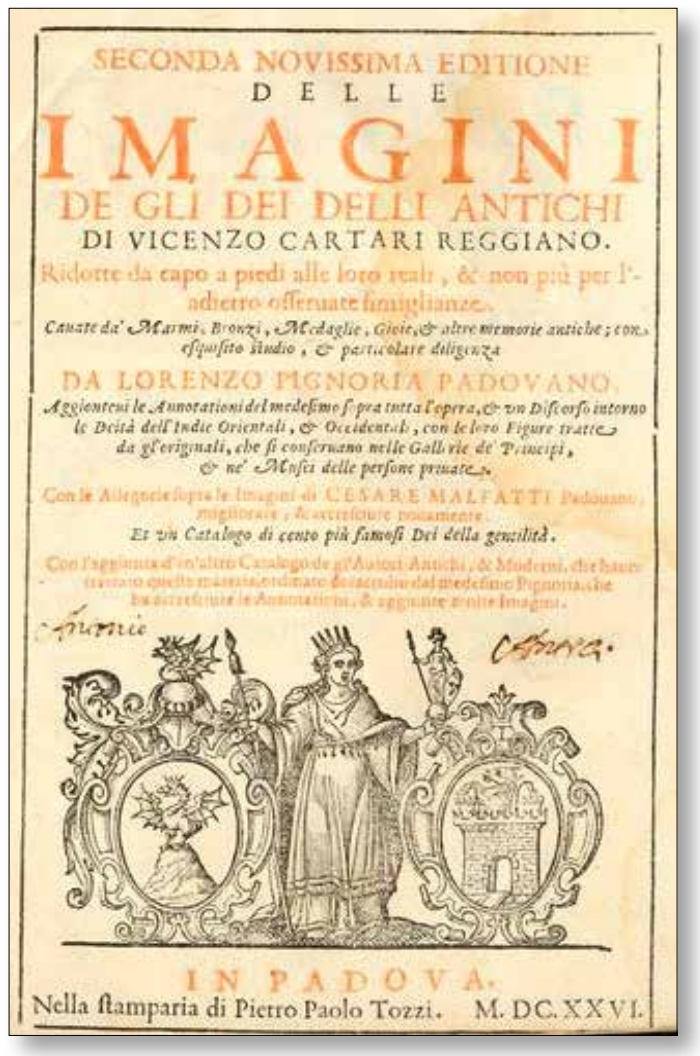

Fig. 7. Vicenzo Cartari (Cartario), Le Imagini... Portada de 1626 .

El retrato de Asteria (imaginariamente, NA: 378) antecede a su historia: casta y bella, es hábil con las plumas. Su nombre y ejemplo (genéticamente, NA: 379) están tomados de las Metamorfosis de Ovidio (2009: VI, v. 108). Sin embargo, lo que se cuenta en el Libro VI (vv. 1-145) no es -puntualmente- la metamorfosis de Asteria sino la de Aracne [fig. 8], quien por distintas razones también podría haber ocupado -en la imaginación de la mexicana- el lugar de Asteria, ya que como sor Juana, "[n]o se distinguía Aracne ni por su patria ni por su cuna, sí por su arte» (Ovidio, 2009: vv. 7-8), que por si fuera poco, era el tejido. ${ }^{26}$ La historia de Aracne y el desafío a Atenea, en el contexto del $N A$, enseguida entra en resonancia con otra: la del lienzo 7, donde Neptuno y Minerva compiten, y donde también (como en Ovidio), triunfa la diosa. El reto orgulloso de Aracne a Atenea es revelador: directo y frontal, y montado sobre una desigualdad en absoluto despreciable (poder humano vs. poder divino ${ }^{27}$ ), está predestinado al fracaso. Asteria, algo más elíptica o elusiva, prefiere evitar la confrontación directa: se transforma (se «aísla») y se mueve (se des-marca o se des-ubica). Además, y según sor Juana (cfr. nota 22), no será el poder mayor (Júpiter) quien la asista, sino otro, pero cuya jurisdicción es aún más beneficiosa para Asteria (Neptuno).

De esta manera, no es difícil trazar cierta metamorfosis a la mexicana: sor Juana, complicada por su afición al estudio y la escritura profanos en un marco religioso, ${ }^{28}$ asediada por su director espiritual y confesor, el padre Núñez de Miranda, es decir, viéndose limitada en su potencial, opta no por el enfrentamiento directo (del cual es casi imposible esperar algo), sino por la elusiva pero coherente estrategia de Asteria que «se valió del mismo ardid para huir con las alas, de las alas, y resistir con las plumas las plumas: cuerdo arbitrio, pues sólo unas a otras pueden impugnarse» (NA: 379). De modo que no será Júpiter (el Rey, en España), de quien espere ser favorecida, sino del mismo Neptuno (el Virrey, en América). ${ }^{29}$ Cuerdo arbitrio: como Asteria (también como Ícaro ${ }^{30}$ ), vesti-

26. En la «Explicación del arco», será Asteria la que «fue de su misma patria forastera» (NA: 405, v. 122).

27. O mejor, y en realidad: poder antropomorfo; (luego, Neptuno-Marqués...).

28. Cfr. la alusión al «estudio» en los versos 19-20 de la «Explicación del arco» (NA: 403).

29. De Neptuno se dice, en la «Explicación del Arco», que es «de las letras el mejor asilo» (NA: 407, v. 188). Y aunque el «viejo dios Neptuno [sea] nada amante de la cultura», «un virrey necesariamente no puede ser Júpiter, pero sí Neptuno, el segundo dios en el Olimpo grecolatino, y, además, dios de los mares y jefe del imperio transmarino, relacionado con el océano» (Hinojo Andrés, 2003: 191).

30. Además de ser una figura frecuente en los trabajos sobre sor Juana, se alude a él, claramente, ya en los primeros versos de la «Explicación del Arco» (NA: 402, vv. 9-12).

IMAGO, NÚM. 4, 2012, 23-39 


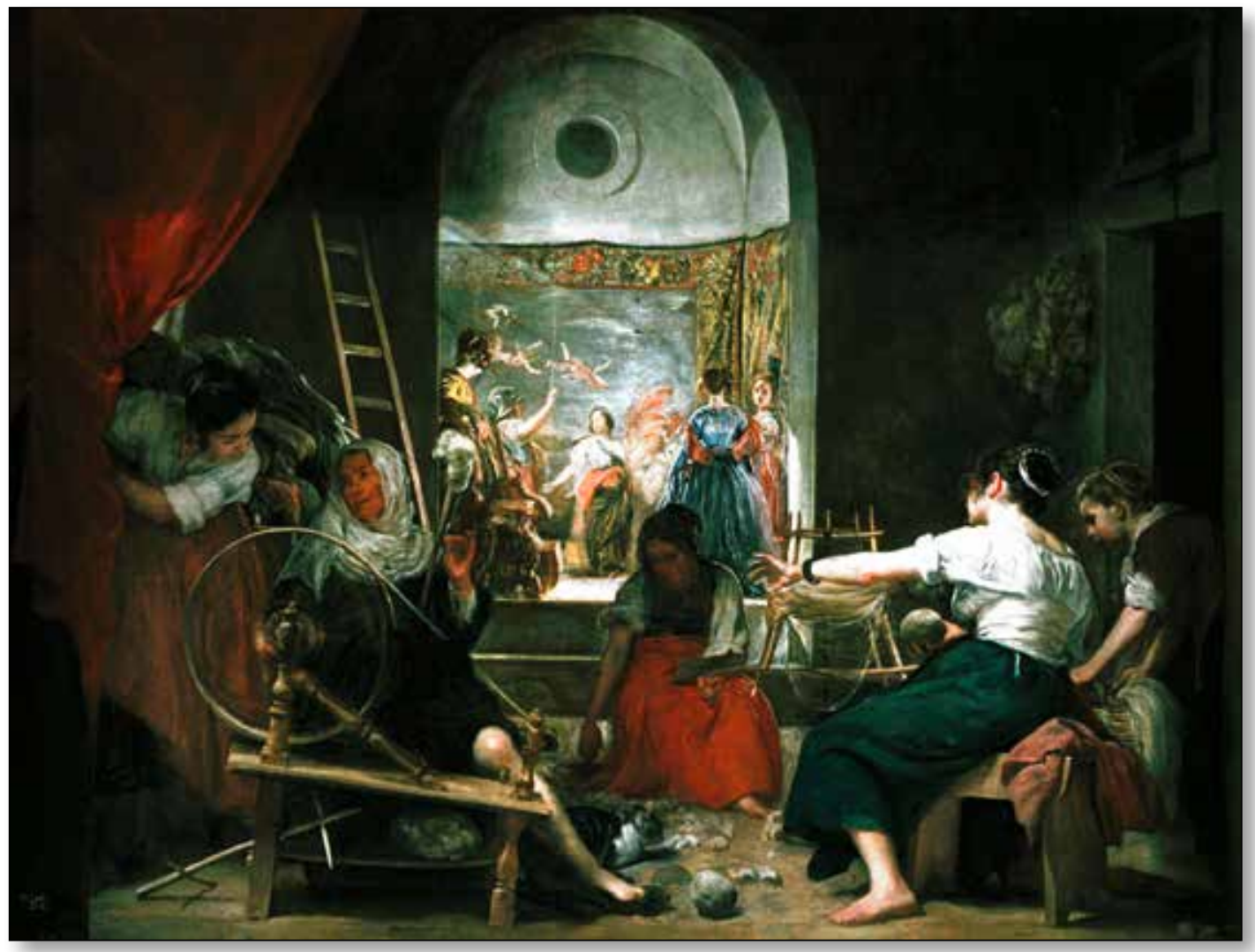

Fig. 8. Diego Velázquez, La fábula de Aracne (Las Hilanderas). Madrid, Museo del Prado, c. 1657.

da de plumas se alzará y caerá el mar, donde «fue condenada a perpetuo movimiento»; pero llegará a ser Delos, que «quiere decir manifestum et apparens" (Ibíd.).

Pero la "cordura" sorjuanina es bastante más elusiva y elíptica, y si bien es posible dicha semejanza (juzgable por lo semejante, no por lo semejado: como queda dicho), el propio lienzo 3 también explicita otra: Delos es una isla, es decir, está rodeada de agua; y por mucho tiempo, según se cuenta, estuvo cubierta: bajo el agua; entonces: ¿no es «nuestra Imperial Méjico» y «su descubrimiento" una clave a la vista de todos? (NA: 380). ¿No tiene México, "émula de Roma», "por armas un águila imperial»?
¿No espera México, bajo «los favores de mejor Neptuno [...] gozar estables felicidades, sin que turben su sosiego inquietas ondas de alteraciones ni borrascosos vientos de calamidades»? (Ibíd.). ${ }^{31}$

México, su ciudad; sor Juana, su poeta: ¿quién es Asteria? Quizás haya que volver a empezar: en el origen fueron las plumas. Y así como el epigrama que cierra el lienzo 3 dedica una estrofa a cada una (Asteria, México), finalmente todo se encuentra escrito, es decir: emplumado. Y esa imagen (como sucedía con la Respuesta) mucho después regresa como otra clave posible: mientras el $N A$ se preguntaba por «aquella casta Asteria, cuya belleza vistió de plumas

31. México-Delos, por si fuera poco (en la «Explicación del arco»), es además donde «nace en plata Diana y Febo en oro» (NA: 406, v. 138; cursivas mías). 
a la deidad de Jove», póstumamente sor Juana se respondía (y de paso a los elogios que su obra despertaba en «las Plumas de la Europa»):

\author{
No soy yo la pensáis, \\ sino es que allá me habéis dado \\ otro sér en vuestras plumas \\ y otro aliento en vuestros labios, \\ y diversa de mí misma \\ entre vuestra plumas ando, \\ no como soy, sino como \\ quisisteis imaginarlo \\ (2004: I, 159, vv. 13-20).
}

\section{PROMETEO DE LIENZOS / DÉ- DALO DE DIBUJOS}

La «Explicación del arco», en verso y como si (emblema de emblema de emblema) buscase trazar el propio arco, que va de la letra muda a la imagen con voz, se configura en tres órdenes métricos o formas poéticas: el romance (vv. 1-68), para la presentación; la silva (vv. 69-284), para descripción sólo de los 8 lienzos; el soneto (vv. 285-298), para la invitación, al virrey, a pasar a la Iglesia, o -también- a elevarse de la laguna (Neptuno, lienzo 1) al cielo (Iglesia inconclusa, lienzo 8). Es muy factible que su primera publicación (aislada y con título propio, ligeramente distinto $^{32}$ ) antecediera a la del $N A$ de Ribera (cfr. nota 11) que lo incluye: en 1952, y con motivo del (desfasado ${ }^{33}$ ) festejo del tercer centenario de su nacimiento, Manuel Toussaint hacía una edición facsimilar de la «Explicación» y ya sugería esta hipótesis, cuyo fundamento residía en que eran versos escritos para ser recitados frente al arco (que explicaban), razón por la cual llama «loa» al poema. ${ }^{34}$

De esta manera, el poema funciona también como la declaración (siguiendo el diseño expresivo del emblema triplex) del texto del $N A$, haciendo que se correspondan conceptos e imágenes: si por un lado se puede ver reunidos a Neptuno y el virrey, a Delos y México, al poder religioso y político, a América y Europa; por otro, es posible leer conjuntamente cierta concepción de la escritura y cierta imagen de quien escribe en la inscripción peculiar de una voz poética esquiva. Incluso, y en consonancia con lo propuesto al inicio, el poema que cierra el $N A$ permite abrir el texto a su situación vital y única: la de sor Juana en 1680, quien revela en "este Prometeo de lienzos" (NA: 403 , v. 37) la cifra de cierto umbral, crítico y tal vez doloroso (pero que expresa la renovación); y en este "Dédalo de dibujos" (NA: 403 , v. 38), la cartografía de una poética en construcción, que si compleja, es al mismo tiempo la expresión que garantiza no ser fácilmente ubicada.

De esta manera, el poema des-pliega (explica) no sólo el texto escrito hacia su imagen, sino ambos hacia la voz. Y de esta voz, incluso del yo lírico del poema, poco cabe agregar si se ha leído (si se viene leyendo) el $N A$ : femenina, culta hasta la erudición, ingeniosa y esquiva pero aislada, quien dice no estar ausente sino que ha afantasmado su presencia con delicada precisión. Sin embargo, pensar así el poema implica un cam-

\footnotetext{
32. Explicación sucinta del arco triunfal que erigió la Santa Iglesia Metropolitana de Méjico, en la feliz entrada del Exmo. Señor Conde de Paredes, Marqués de Laguna, Virrey, Gobernador y Capitán General de esta Nueva España y Presidente de la Real Audiencia y Cancillería; que hizo la Madre Juana Inés de la Cruz, religiosa del Convento de San Jerónimo de esta Ciudad.

33. Sor Juana nació en 1648 y no en 1651 (cfr. Alatorre, 2006: 104, nota 3).

34. La hipótesis de que haya sido efectivamente recitado frente al virrey también se apoya (sólidamente) en la mención que Ramírez Santibañez hace en su Piérica narración [...] de 1680; allí dice que «Una cómica [actriz] explicó» (cfr. Alatorre, 2007: 26). Cfr. también: López Poza, 2003: 243 y Parodi, 2008: 471. En este sentido, no parece probable que -como sugiere Olivares Zorrilla- la «Explicación del arco» esté «pensada para sustituir la imagen visual, no para complementarla»; sobre todo, cuando ella misma afirma, poco más adelante: «La presencia de los emblemas en el discurso poético es, pues, un gesto y un guiño cultural, algo para ser reconocido evocando una imagen en la memoria del oyente» (1995: 368-369).
} 
bio doble de dirección, puesto que nadie, o al menos muy pocos, escucharon o leyeron el poema después de haber leído (lo que hoy conocemos como) el $N A$, ya que no fue esa la secuencia «original» del trabajo, que sólo más tarde y subsidiariamente, apareció como texto legible. Así, y en primer lugar, no son el texto y la imagen quienes se despliegan (en el poema) hacia la voz, sino la voz la que despliega a ambos (en el aire); y en segundo lugar, el $N A$ no es un texto para ser (punto por punto, o solamente) leído, es decir: su potencia excede el libro, ocupa la ciudad, y necesariamente, si no se pierde, pronto se transforma. El $N A$, como tantas otras ideas de (arcos), forma parte del arte efímero: antiguos y extraños ready-mades. ${ }^{35}$ Y es realmente llamativo: los textos como el Neptuno Alegórico son, fundamentalmente, ideas de que han sido escritas, lo que los coloca a una distancia menos irónica que paradójica de la filosofía y el ensayo, y a una distancia menos confusa que atractiva de la historia y el diario (no íntimo sino público, cfr. Aira, 2008).

Y en más de un sentido, como se ha visto, sor Juana filosofa sobre la relación entre infinito y límite, entre modelo (u original) y copia, entre idea y clave; ensaya «maneras de escribir» (en prosa y en verso), concibiendo procedimientos y métodos; historiza las virtudes de los gobernantes y las opiniones influyentes sobre el tema, tanto como el origen de ciertas palabras y ciertos personajes; y por último confecciona, para 1680 (y en ciertos aspectos: puntualmente para el 30 de noviembre), el diario no sólo de acontecimientos y costumbres, de tramas político-culturales y esplendores artísticoliterarios, sino de sucesos menores, individuales y hasta privados, que pudiendo pasar desapercibidos encuentran -cifrados en un arco- una expresión posible.

\section{BIBLIOGRAFÍA}

AIRA, C. [2008]. «La intimidad», Boletín 13/14, Rosario, 6-12.

Alatorre, A. [1986]. "Sor Juana y los hombres", Estudios, 7, 7-27.

Alatorre, A. [1987]. "La Carta de sor Juana al P. Núñez», NRFH, 35, 591-673.

Alatorre, A. [2006]. "Hacia una edición crítica de sor Juana (Segunda Parte)", NRFH, 54, 103-142.

Alatorre, A. (Comp.). [2007]. Sor Juana a través de los siglos, 2 t., México DF, El Colegio de México-UNAM.

Alatorre, A. [2010]. "En torno al Neptuno Alegórico de Sor Juana», en NRFH, 58, 269-278.

Alciato, A. Emblemas, Madrid, Akal, 1993.

Arenal, E. [2009]. "Introducción», en sor J. I. DE LA Cruz, Neptuno Alegórico, Madrid, Cátedra, 11-45.

BAJTín, M. [1990]. La cultura popular en la Edad Media y el Renacimiento, México, Alianza.

Benjamin, W. El origen del "Trauerspiel» alemán, Madrid, ABADA, 2006.

Bouzy, C. [1993]. «El emblema: un nuevo lugar estético para los antiguos lugares éticos», Criticón, 58, 35-45.

\begin{abstract}
35. Lope de Vega, en Relación de las fiestas que [...] Madrid hizo [...] [a] San Isidro, explicita (en función de la lectura de textos como el $N A$ ): «No se deben pues leer tales relaciones con más ánimo que la diferencia humilde que se les permite, como un cuerpo simple a quien falta el alma de las sentencias y del ejemplo» Cit. en López Poza, 2003: 241; cfr. también Olivares Zorrilla (1995: 368). Y si, como Arenal describe, el «arco era, pues, como un enorme libro de emblemas al aire libre con todos sus 'páginas' abiertas a la vez» (2009: 21), no es difícil ver allí el Ready-made malheureux (1919), cuyas instrucciones envió Marcel Duchamp a su hermana Suzanne desde Buenos Aires como presente por su casamiento con Jean Crotti. No obstante, cabe recordar que «para los surrealistas, la alegoría ya no era un método pedagógico del poder, sino una herramienta de autoexploración psicológica y política de carácter revolucionario, que obligaba a reconducir la relación con la realidad sin pasar por el cartesianismo del pensamiento capitalista. Para el dadaísmo, el proceso de desarticulación de la creación, como en el caso de los 'ready-mades' duchampianos, forzaba aun más la dislocación entre lo que se ve y la función que el objeto proyecta, al proponer al espectador que la clave de correlación entre una cosa y otra está en el contexto» (Marzo, 2010: 299).
\end{abstract}


Buxó, J. P. [1959]. "Prólogo», en J. P. Buxó (ed.), Arco y certamen en la poesía mexicana colonial (siglo XVII), México DF, Universidad Veracruzana, 7-50.

Buxó, J. P. [2002]. El resplandor intelectual de las imágenes, México DF, UNAM.

De la Cruz, sor J. I. [2004]. Obras completas I. Lírica personal y Obras completas IV. Comedias, sainetes y prosa, México DF, FCE, (edición, introducción y notas: [I] Alfonso Méndez Plancarte; [IV] Alberto G. Salceda).

De la MAZA, F. La mitología clásica en el arte colonial de México, México DF, UNAM, 1968.

Deleuze, G. [1989]. El pliegue, Barcelona, Paidós.

Deleuze, G. [2002]. Spinoza y el problema de la expresión, Madrid, Editora Nacional.

Deleuze, G. En medio de Spinoza, Buenos Aires, Cactus, 2006.

Egan, L. Diosas, demonios y debate: Las armas metafísicas de Sor Juana, Salta, Biblioteca de Textos Universitarios, 1997.

García Arranz, J. J. [2002]. «La imagen jeroglífica en la cultura simbólica moderna. Aproximación a sus orígenes, configuración y funciones», en A. P. Bernat Vistarini y J. T. Cull (coords.), Los días del Alción: emblemas, literatura y arte del Siglo de Oro, España, Universitat de les Illes Balears, 229-255.

GinZBURG, C. [1994]. Mitos, Emblemas e Indicios: Morfología e historia, Barcelona, Gedisa.

Glantz, M. [1994]. «Prólogo», SOR J. I. DE LA Cruz, Obra selecta, Caracas, Ayacucho.

GLANTZ, M. «El jeroglífico del sentimiento: la poesía amorosa de Sor Juana», Ensayos sobre Literatura Colonial. Obra reunida I, México DF, FCE, 2006, 578-588.

Graves, R. Los mitos griegos, v. I, Buenos Aires, Alianza, 1996.

GRIMAL, P. Diccionario de mitología griega y romana, Buenos Aires, Paidós, 1997.

Grossi, V. [2007]. Sigilosos v(u)elos epistemológicos en sor Juana Inés de la Cruz, Madrid, Iberoamericana-Vervuert.

GRUZINSKI, S. [2003]. «Los efectos admirables de la imagen barroca», La guerra de las imágenes, México DF, FCE, 102-159.

IMAGO, NÚM. 4, 2012, 23-39
HinOJO ANDRÉs, G. [2003]. «Fuentes clásicas y renacentistas del Neptuno alegórico», Nova Tellus, 21-2, 177-202.

LóPez PozA, S. [2003]. «La erudición de Sor Juana Inés de la Cruz en su Neptuno Alegórico», La perinola, 7, 241-270.

Marzo, J. L. [2010]. La memoria administrada. El barroco y lo hispano, Madrid, Katz.

Morales Folguera, J. M. [1992]. «Los Cabildos municipales como promotores de la Fiesta Barroca en Andalucía y América: México y Málaga», Actas de las X Jornadas de Andalucía y América, Sevilla, 447-455.

Olivares Zorrilla, R. [1995]. “'El sueño’ y la emblemática», Literatura mexicana, 6-2, 367-398.

Olivares Zorrilla, R. [2006]. «Noche órfica y silencio pitagórico en Sor Juana», Prolija memoria, 1-2, 91-112.

Ovidio. [2009]. Metamorfosis, Madrid, Alianza.

PARodi, C. [2008]. «El lenguaje de las fiestas: arcos triunfales y villancicos», Destiempos. com, 14, 472-483.

Paz, O. [1998]. Sor Juana Inés de la Cruz o las trampas de la fe. México DF, FCE.

Puccini, D. [1997]. Una mujer en soledad, México DF, FCE.

Rodríguez DE la Flor, F. Barroco, Madrid, Cátedra, 2002.

Rodríguez De la Flor, F. [2009]. Imago. La cultura visual y figurativa del barroco, Madrid, ABADA.

SABAT DE Rivers, G. [1992]. «El 'Neptuno' de Sor Juana: fiesta barroca y programa político», Estudios de Literatura Hispanoamericana, Barcelona, PPU, 241-277.

SAlCEDA, A. G. [2004]. «Introducción», en SOR J. I. DE LA CRUZ, Obra completa IV, México DF, FCE, VII-XLVIII.

Scavino, D. «Sor Juana Inés de la Cruz», El señor, el amante y el poeta, Buenos Aires, Eterna Cadencia, 2009, 123-140.

Serrato Córdova, J. E. [1995]. «Juegos de ingenio y erudición en Primero Sueño», Literatura Mexicana, 6-2, 435-445.

SigüENZA y GónGORA, C. [1984]. «Teatro de virtudes políticas que constituyen a un príncipe», Seis obras, Caracas, Ayacucho, 167-242. 
